Niepełnosprawność. Dyskursy pedagogiki specjalnej

$\mathrm{Nr} 24 / 2016$

Disability. Discourses of special education

No. $24 / 2016$

Dorota Krzemińska

Uniwersytet Gdański

\title{
Festiwal Akcept w kontekście karnawału M. Bachtina. Rzecz o dorosłych z niepełnosprawnością intelektualną w lokalnych inicjatywach kulturalno-edukacyjnych
}

\author{
Akcept Festival in the context of M. Bakhtin's carnival. \\ On adults with intellectual disabilities in the local cultural \\ and educational initiatives
}

In the text the author presents Akcept Festival and Open Space Technology dabate in the context of Bakhtinian carnival. Akcept Festival as a local cultural and educational initiative appears an interesting and important artistic event which - according to Bakhtinian carnival - makes ordinary life and its rules and regulations temporarily suspended and reversed, which eventually extracts all individuals - either with intellectual disabilities or without disabilities from noncarnival life. Carnival transforms the world making it upside down and violates all former ideologies, hierarchical positions, social roles and relations. Bakhtinian carnival affects people into collaboration and dialogue. Particularly it empowers people with intellectual disabilities (voice) to perform in the space of dialogical immanence, expressing their own individual meanings and senses. Carnival makes voices of people with intellectual disabilities and without disabilities interact and flourish that results in a genuine dialogue between them.

Słowa kluczowe: dorośli z niepełnością intelektualną, inicjatywy kulturalne i edukacyjne, upełnomocnienie głosu, współpraca i dialog, koncepcja karnawału M. Bachtina

Keywords: adults with intellectual disabilities, cultural and educational initiatives, voice empowerment, collaboration and dialogue, Bakhtinian carniva

\section{Wprowadzenie}

Bezpośrednim impulsem do refleksji nad pewnymi aspektami związanymi z przestrzenią funkcjonowania dorosłych osób z niepełnosprawnością intelektualną jest wydarzenie na trwałe wpisane w kalendarium dorocznych imprez artystycznych w Trójmieście - Festiwal Akcept. Już na wstępie chcę jednak doprecyzować, iż nie o samym festiwalu będzie tu mowa (każdej bowiem z jego siedmiu 
zrealizowanych już edycji można by poświęcić osobne i obszerne opracowanie). Festiwal Akcept stanowi w tym tekście pretekst do tego, by poddać pod namysł i dyskusję zagadnienie swoistego zaistnienia $\mathrm{w}$ debacie, zabrania głosu we własnym imieniu, (za)komunikowania własnych znaczeń i sensów nadawanych sobie i światu - a tym samym realnego wykroczenia poza "milczącą" pozycję, w jakiej najczęściej umiejscowione są osoby z głębszą niepełnosprawnością intelektualną. I choć Akcept to niejako „skondensowana dawka” widowisk teatralnych, przeplatanych warsztatami i wernisażami, które nadają festiwalowi naturę artystycznego eventu, to intencją mojej wypowiedzi nie jest skoncentrowanie się na samych przedstawieniach jako twórczej ekspresji występujących na scenie osób, lecz skupienie się na innej, integralnej części festiwalu: debacie - dyskusji zorganizowanej $\mathrm{w}$ konwencji tzw. technologii otwartej przestrzeni. Biorą w niej aktywny udział osoby z głębszą niepełnosprawnością intelektualną, których uczestnictwo odbywa się na równych prawach i w partnerskiej, możliwie najbardziej symetrycznej relacji ze wszystkimi dyskutantami, o bardzo zróżnicowanych (często nieporównywalnych) kompetencjach i możliwościach. A to - moim zdaniem - stanowi doniosły przykład wydobywania się tej grupy z „bezgłośnej”, „niemej” pozycji (Tortosa 1986; Bhabha 2008, 2010), jaką wydają się najczęściej zajmować w społecznych lokalizacjach.

Chcąc pokazać jak widzę ów proces, który dokonuje się podczas Festiwalu Akcept, odwołam się do metafory karnawału/karnawałowości M. Bachtina, poszukując $w$ poglądach rosyjskiego badacza interpretacji dla interesującego mnie zjawiska, jakim jest dekonstrukcja i przemieszczenia w polu znaczeń odnoszących się do osób z niepełnosprawnością intelektualną, co staje się możliwe podczas imprezy jaką jest festiwal. $Z$ jednej strony festiwal i karnawał to fenomeny o zbliżonej naturze, porównywalne jeśli chodzi o cele i funkcje jakie spełniają: oba bowiem zyskały rangę wydarzeń na swój sposób odświętnych, niezwykłych, sankcjonują i uprawomocniają (działania)/zachowania odbiegające od codziennych, potocznych, z aprobatą zamieniając je na takie, które wyłamują się z tradycyjnego porządku i powszedniej rutyny - „desakralizują codzienność”. Poszukując części wspólnych, łączących festiwal i karnawał w definicjach W. Kopalińskiego (1983) oraz W. Pessela (http://kulturalny.uw.edu.pl/luty21/karnawal.htm) nietrudno skonstatować, iż oba zjawiska wyróżniają się pośród zdarzeń zwykłych, przeciętnych, prozaicznych - jakich wiele i stają się swoistym świętem/ czymś odświętnym, uroczystością, wydarzeniem żywym, radosnym, wesołym. Oznaczają czas, gdy codzienny rygor i obowiązki ustępują miejsca imprezom, konkursom, „ożywionym zbiegowiskom", które m.in. gromadzą liczne środowiska i sprzyjają nawiązywaniu kontaktów, w tym także podczas ożywionych i hałaśliwych zabaw.

W niniejszym opracowaniu chcę zatem, przybliżając Festiwal Akcept z zaakcentowaniem organizowanej $w$ jego trakcie dyskusji w tzw. technologii otwar- 
tej przestrzeni, przyjrzeć się temu wydarzeniu w kontekście karnawału/karnawalizacji, które M. Bachtin pojmuje jako nadzwyczajną i specyficzną okoliczność wspólnego bycia różnych/różniących się podmiotów, podczas której dochodzi do swoistego równouprawnienia sposobów komunikowania się odmiennych środowisk i grup społecznych. Istotą karnawału jest bowiem zawieszenie/unieważnienie obowiązujących zwyczajowo porządków społecznych (i moralnych), izonomia języków i głosów, afirmacja wielogłosowości oraz przyzwolenie na różnorodność konwencji i stylów. Istotę karnawału celnie uchwyciła M. Romanowska (http:// www.filg.uj.edu.pl/documents/41616/105797965/Magdalena_Romanowska-streszczenie.pdf), pointując, iż Bachtinowski „karnawał biorąc w nawias uporządkowany zhierarchizowany świat stosunków międzyludzkich stwarza wyjątkową sytuację oczyszczającą słowo od wszelkiego życiowego automatyzmu i pretensji na obiektywność, zmusza człowieka do odkrycia wewnętrznego jądra własnego człowieczeństwa". Tak rozumiana idea karnawału/karnawalizacji jawi się interesującą inspiracją teoretyczną dla przyjrzenia się fragmentowi przestrzeni międzyludzkiej konstruowanej przez relacje/stosunki i społeczne sytuacje komunikowania się pomiędzy osobami pełnosprawnymi i z głębszą niepełnosprawnością intelektualną. Zwykle bowiem, w tradycyjnie zakreślonej przestrzeni społecznego (współ)bytowania, podmioty te pozostają w niesymetrycznej relacji, w której uprzywilejowaną, nadrzędną pozycję wydaje się zajmować pełnosprawny, który wycisza głos osoby z niepełnosprawnością intelektualną, nawet jeśli zostaje on wyartykułowany w imieniu tegoż bądź niejako „w zastępstwie", pełnionym $\mathrm{w}$ dobrej wierze i podyktowanym najlepszymi intencjami wspierania słabszego. [Takiemu kontekstowi relacji osób pełnosprawnych i z niepełnosprawnością (intelektualną) poświęcone są publikacje m.in. D. Krzemińskiej (2006, 2012), J. Rzeźnickiej-Krupy (2007) czy S. Danfortha (1997)]. Wszelkie zatem fenomeny kreowane w rzeczywistości, które włączają się w starania, by przełamać utrwalony w ten sposób ład/porządek społeczny, wydają się warte wyeksponowania i prezentacji, co niniejszym czynię, znajdując zarazem jako ciekawą płaszczyznę interpretacji i namysłu dla Festiwalu Akcept karnawału/karnawalizację M. Bachtina.

\section{O Festiwalu Akcept i Technologii Otwartej Przestrzenie w zarysie}

Zanim przejdę do omówienia podstawowego wątku w tym tekście, przybliżę jedynie skrótowo ideę Festiwalu Akcept, akcentując jedną z integralnych jego części (która stanowi ważny dla całokształtu tej imprezy element), jakim jest żywa, swobodna dyskusja organizowana z zastosowaniem tzw. technologii otwartej przestrzeni. Jest to ta część festiwalu, w której aktywnie uczestniczą dorosłe osoby z niepełnosprawnością intelektualną, zabierając głos/ wypowiadając się we 
własnych sprawach, o sobie, na swój temat, niezależnie od tego jak głębokie mogą być skutki doświadczanej niepełnosprawności, ujawniające się także jako utrudnienia w komunikowaniu się czy zdolności do autorefleksji.

Sam zaś Festiwal Akcept stanowi jedno ze znaczących wydarzeń artystyczno-kulturalnych, które zostało zainicjowane w Gdańsku w 2009 roku jako przegląd twórczości teatralnej osób z niepełnosprawnością intelektualną (http:// akcept.gak.webd.pl/), stając się z czasem rozpoznawalną impreza/eventem na mapie wydarzeń Trójmiasta, jaki cyklicznie odbywa się na scenie teatru Gdańskiego Archipelagu Kultury w dzielnicy Orunia. Jest to wydarzenie organizowane przez kilka podmiotów, choć niewątpliwym motorem działań są dwa z nich: Gdański Archipelag Kultury - Teatr GAK (http://www.wyspaskarbow.gak.gda. pl/o-nas/gdaski-archipelag-kultury - który jest instytucją "rozrzuconą" po całym Trójmieście. Stąd metafora archipelagu, która faktycznie oddaje jego naturę, dookreślając różne, często oddalone od siebie i umiejscowione w różnych dzielnicach Gdańska, placówki, jednolite jakkolwiek w charakterze realizowanych idei zogniskowanych wokół działań kulturalnych i artystycznych). Drugim z pomysłodawców i organizatorów Festiwalu jest Fundacja Rozwoju Integracji Społecznej „Akces” (podmiot prowadzący Środowiskowy Dom Samopomocy NOWINY; http://frisakces.wixsite.com/fundacja). Partnerami w organizacji Festiwalu są: Zakład Pedagogiki Specjalnej Uniwersytetu Gdańskiego oraz Grupa IM+.

Festiwal Akcept to artystyczne spotkanie wielu podmiotów, które każdego roku zabierają głos w wielostronnym dialogu, wyrażanym głównie przez prezentacje teatralne, jak i muzyczne, plastyczne i inne formy ekspresji. Festiwal Akcept to nie tylko impreza dedykowana osobom z niepełnosprawnością (intelektualną), choć niewątpliwie znajdują się one w jej centrum. To wydarzenie będące niejako pretekstem i zachętą zarazem do publicznej dyskusji oraz namysłu nad zjawiskiem inności i różnorodności, które wpisane w przestrzeń życia codziennego nieustannie skłania do stawiania pytań o miejsce i rolę osoby niepełnosprawnej oraz tych, którzy jej towarzyszą, na arenie zdarzeń potoczności.

Moim udziałem jest członkostwo w radzie programowej festiwalu, toteż angażując się $\mathrm{w}$ organizację tego przedsięwzięcia, sytuuję się zarazem $\mathrm{w}$ innej z pełnionych przeze mnie ról - badacza społecznego i podejmuję zadanie pokazania Akceptu jako przestrzeni, w której dochodzi do spotkania dwóch podmiotów: pełnosprawnego i z niepełnosprawnością intelektualną. Podmioty te scala twórczość/ recepcja kreacji (stanowiących prezentacje rożnych form sztuki) z wyeksponowaniem spektakli teatralnych oraz inne, wkomponowane w całość trzydniowego festiwalu, wydarzenia. Integralną częścią festiwalu jest dyskusja zorganizowana $\mathrm{w}$ konwencji tzw. technologii otwartej przestrzeni. Uczestniczą w niej - o czym powyżej sygnalizowałam - osoby z niepełnosprawnością intelektualną, które nieczęsto mają sposobność do aktywnego zaistnienia w publicznej 
debacie, co zwykle wiąże się także z koniecznością odnalezienia się w sytuacji społecznej ekspozycji i zmierzenia się m.in. z napięciem towarzyszącym wystąpieniom na forum. Chcę także zwrócić uwagę na fakt, iż publiczne wydarzenia o charakterze debat, konferencji, seminariów, forów czy innych spotkań, które choć z założenia poświęcone/ dedykowane są osobom z niepełnosprawnością intelektualną (oraz problematyce skupionej wokół tej społecznej grupy), zwykle odbywają się bez ich obecności, a w każdym razie najczęściej bez ich czynnego/aktywnego uczestnictwa. Festiwal Akcept $i$ realizowana w jego ramach dyskusja przełamuje tę konwencję, udzielając zaś głosu niepełnosprawnym wydaje się wpisywać w pole działań, które dekonstruują znaczenia przypisywane temu środowisku jako (nie)zdolnemu do wykroczenia poza „bezgłośną", ugruntowaną przez lata pozycję.

W niniejszym opracowaniu, tytułem egzemplifikacji odwołuję się do edycji Festiwalu Akcept z 2013 roku, którego temat wiodący brzmiał: „Pomiędzy upełnomocnieniem a manipulacją - wokół relacji z osobą z niepełnosprawnością intelektualną", stanowiąc tym samym temat dla dyskusji realizowanej w ramach festiwalu z zastosowaniem technologii otwartej przestrzeni. Zamysłem tak zaprojektowanej dysputy jest zaproszenie do udziału w niej możliwie szerokiego kręgu podmiotów, często o bardzo zróżnicowanych, a nawet bardzo odmiennych (bardzo różniących się) kompetencjach, reprezentujących rozmaite profesje i zainteresowania, wywodzących się z różnych lokalizacji, dysponujących określonym kulturowym kapitałem. Głos każdego z nich jawi się tak samo ważny i doniosły, stąd pomysł by w "otwartej przestrzeni” mógł zostać nie tylko wypowiedziany, ale i uważnie wysłuchany ${ }^{1}$.

Technologia Otwartej Przestrzeni (TOP) - Open Space Technology (http:// www.openspaceworld.com/, http://openspaceworld.org/wp2/) to metoda organizowania spotkań (np. seminariów, konferencji czy sympozjów gromadzących od 12 do 2000 osób), którą zainicjował w 1983 roku H. Owen (http://www.openspaceworld.com/brief_history.htm). Szczególną wyróżniającą cechą spotkań realizowanych w technologii otwartej przestrzeni jest to, że nie wymaga ona żadnego przygotowania się do niej uczestników, nie istnieje też wcześniej przygotowany program (czy harmonogram), nie powołuje się też konkretnych (grup) osób odpowiedzialnych za planowanie czy zarządzanie przedsięwzięciem, poza upowszechnieniem oczywistej informacji, kto jest podmiotem organizującym spotkanie, $\mathrm{w}$ jakim terminie i miejscu będzie ono zlokalizowane oraz sprecyzowanie tematu (wokół którego ogniskować się będą rozmowy/dyskusje).

1 Podane powyżej informacje dotyczące Festiwalu Akcept oraz dyskusji w technologii otwartej przestrzeni zostały opracowane i zredagowane przez autorkę tekstu na potrzeby materiałów promujących festiwal i są (w tej samej treści) dostępne na stronie internetowej festiwalu http://www.akcept. gak.webd.pl/ 
W celu poprowadzenia spotkania wyłoniona zostaje przez podmiot organizujący przedsięwzięcie konkretna osoba, która wyjaśnia przybyłym zasady regulujące przebieg całości wydarzenia. Uczestnicy sami określają obszar własnych zainteresowań, mieszczących się w polu tematu spotkania: oznacza to, że każdy indywidualnie bądź też kilka osób wspólnie przedstawia propozycje, które zostają zanotowane na kartce, ta zaś po przekazaniu osobie prowadzącej zostaje umieszczona na widocznej dla wszystkich tablicy. Propozycji wątków do dyskusji może być wiele, gdyż zasadniczo każdy kto zechce może zgłosić swój pomysł. Kiedy wszystkie propozycje zostaną przedstawione: w zależności od tego ile ich jest - albo zostaną pogrupowane i wyłania się z nich grupy tematyczne, jeżeli jest ich mniej, nie ulegają grupowaniu. Powstaje w ten sposób jak gdyby kilka/kilkanaście sekcji czy grup dyskusyjnych, w których gromadzą się uczestnicy spotkania. Osoba prowadząca wyznacza czas i miejsce spotkań poszczególnych zespołów jeśli jest to odpowiednio duża sala można „pogrupować się"/ umiejscowić każdą z grup w różnych jej miejscach, a jeśli są takie możliwości - dyskutanci rozlokowują się, przechodząc do innych pomieszczeń. Co ważne, każdy uczestnik może brać udział w dyskusjach toczących się w różnych sekcjach/grupach, swobodnie przemieszczając się pomiędzy nimi. Oznacza to, że początkowa decyzja o dołączeniu do konkretnej grupy tematycznej może ulec zmianie w zależności od treści toczących się dyskusji bądź adekwatnie do ewoluujących zainteresowań/potrzeb uczestnika. Po upływie czasu przeznaczonego na dyskusję w sekcjach/grupach uczestnicy ponownie gromadzą się $\mathrm{w}$ jednym miejscu/sali i zwięźle prezentują oraz podsumowują treść odbytych „w rozproszeniu" rozmów, wypracowując i uściślając wypływające zeń wspólne konkluzje bądź ustalenia (które mogą dotyczyć (planów) działań, przedsięwzięć na przyszłość).

Metoda, którą opisuję, o czym sygnalizowałam już powyżej, nie wymaga żadnego przygotowania poszczególnych uczestników, a wystąpienia przybyłych na spotkanie nie podlegają żadnym wcześniejszym ustaleniom, ani też nie wyznacza się konkretnych ram organizacyjno-czasowych, które ostatecznie przyjmowałyby postać programu (konferencji, seminarium, spotkania itp.). Głos w dyskusji może zabierać każdy biorący udział w wydarzeniu, toteż wybór TOP jako metody organizującej dyskusję podczas festiwalowych dni jest w pełni przemyślany i celowy, gdyż zakłada i umożliwia realne partycypowanie w rozmowach osób niepełnosprawnych (intelektualnie), niezależnie od przejawianych przez nie utrudnień czy ograniczeń związanych zwłaszcza ze sferą komunikowania się, zdolności do (auto)refleksji i formułowania własnych myśli, sądów oraz ekspresji uczuć i emocji. 
Bo niepetnosprawny też ma swój rozum $i$ sam gadać może, a nie, że nas nie pytaja, co my chcemy, nie?!

\section{Osoby z niepełnosprawnością intelektualną własnym głosem podczas dyskusji $\mathrm{w}$ technologii otwartej przestrzeni}

Poniżej przedstawię fragmenty z przebiegu prezentowanego $\mathrm{w}$ tej publikacji wydarzenia, odwołując się do poczynionych drogą obserwacji (uczestniczącej) spostrzeżeń oraz sporządzonych notatek terenowych (Hammerslay, Atkinson 2000; Angrosino 2010). Jak bowiem wcześniej nadmieniłam, mój udział w Festiwalu Akcept łączy w sobie dwojaką rolę: współorganizatorki i badaczki, dla której rozmaite przestrzenie/obszary codzienności konstruowanej zarówno przez zdarzenia powszednie, potoczne, zwyczajne, jak i odświętne, niezwykłe, doniosłe, uroczyste stają się sposobnością, by przyjrzeć się, poddając analizie i namysłowi funkcjonujące w nich osoby z niepełnosprawnością intelektualną. Własne usytuowanie jako badacza doświadczającego spontanicznie wydarzających się zdarzeń z udziałem interesującej mnie grupy upoważnia mnie, jak sądzę, by podejmowaną przez siebie aktywność określić jako zapis (wycinka / fragmentu z) życia codziennego, mieszczącego się w polu (zainteresowań) antropologii codzienności (por. m.in. Burszta 1998; Szarota 1996; Sztompka 2009). Nie oznacza to jakkolwiek, iż uczestnicząc $\mathrm{w}$ różnych wydarzeniach - spontanicznych, niezaplanowanych czy też takich, w których mój udział jest w pełni intencjonalny i zamierzony, realizuję rolę badacza, mając uprzednio przygotowany i metodologicznie dookreślony zamysł penetracji danego wycinka rzeczywistości. Istotę mojego działania $\mathrm{w}$ takich okolicznościach trafnie obrazuje pogląd R. Sulimy (2000, s. 7-9), który wyłuszczając swój pogląd odnoszący się do antropologii życia codziennego oraz penetrowania fenomenów weń wpisanych wyjaśnia: „zjawiska codzienności, które tradycyjnie określiłoby się jako "przedmioty badań”, są dla mnie przedmiotami zmagań, czyli elementami scenariuszy życiowych (...). Pisze tę antropologię "działający" realnie w życiu, nawet niekiedy spacerowicz, który świat "analizuje krokami", a nie badacz, który wkracza w teren z etnograficznym kwestionariuszem, z gotowym projektem jego całości. (...) Sens codzienności jest w każdej chwili "tuż przed nami", jak sens potocznej rozmowy. (...) Tylko w rzeczach i słowach, które nas otaczają, „przebłyskują" jakieś „,codzienne historie. (...) Antropolog codzienności „zawsze" jest na badaniach: przy domowym obiedzie, w supermarkecie, w uniwersyteckiej kawiarni, na ulicy, podczas snu. (...) Antropolog czuje się zarazem "swojsko" i „obco" w codzienności, potrafi fascynować się dramatami i banałami (...). Działając w realnym życiu, raportowanie staje się sposo- 
bem jego życia, z antropologicznego punktu widzenia dobrym, jak każdy inny sposób".

Postępując w sposób obrazowo zarysowany przez R. Sulimę, partycypowałam w Festiwalu Akcept jako wycinku rzeczywistości, który w potoku wielu rozmaitych zdarzeń codziennych, banalnych wyłamuje się z ich rutyny i ustanawia czas odświętny, niezwyczajny, właściwy naturze zjawiska jakim jest festiwal (czy karnawał). Biorąc udział w tym wydarzeniu, raportuję jego fragmenty z zamiarem skoncentrowania się na aktywności funkcjonujących $w$ nim osób dorosłych z niepełnosprawnością intelektualną, dla których Festiwal jako lokalna inicjatywa kulturalno-edukacyjna stał się przestrzenią do realnego zaistnienia w dyskusji, wypowiedzenia się własnym głosem oraz bycia z uwagą i cierpliwością wysłuchanym.

Grupę osób z niepełnosprawnością intelektualną, biorących udział w dyskusji realizowanej metodą technologii otwartej przestrzeni, stanowili uczestnicy Festiwalu Akcept, głównie aktorzy zespołów teatralnych i muzycznych, którzy występowali podczas trzech festiwalowych dni oraz publiczność i goście - uczestnicy oraz opiekunowie/ terapeuci placówek wsparcia dla dorosłych osób z niepełnosprawnością z Trójmiasta i okolic. Wśród zaproszonych znaleźli się także przedstawiciele instytucji publicznych (takich jak m.in. MOPS, MOPR, PEFRON, Urząd Miasta: Gdańska, Sopotu, Gdyni), reprezentanci władz miasta, organizacji pozarządowych, politycy, radni, jak i nauczyciele szkół specjalnych, młodzież szkolna oraz wykładowcy i studenci trójmiejskich uczelni. Formując grupę dyskutantów uczestniczących w spotkaniu realizowanym metodą TOP łącznie stanowili zbiorowość około 60 osób.

Po zgromadzeniu się w sali przeznaczonej na dyskusję (sala teatralna GAK, Dworek Artura - http://www.gak.gda.pl/dworekartura) osoba prowadząca, stosując się do reguł postępowania $\mathrm{w}$ ramach opisywanej metody, objaśniła zasady przebiegu dyskusji, ale też, zważywszy na udział osób z niepełnosprawnością intelektualną zadbała o to, by upewnić się jak rozumieją pojęcia zawarte $\mathrm{w}$ haśle wiodącym Festiwalu oraz wspólnie doprecyzowano/dookreślono ich znaczenie. (Dla przypomnienia podam, iż w niniejszym tekście odwołuję się do edycji Festiwalu Akcept z 2013 roku, którego hasłem było: „Pomiędzy upełnomocnieniem a manipulacją - wokół relacji z osobą z niepełnosprawnością intelektualną"). Organizatorzy spotkania baczyli również na to, aby wśród (a dosłownie: pomiędzy nimi, obok, blisko towarzysząc) osób z niepełnosprawnością intelektualną zgromadzonych $\mathrm{w}$ sali znaleźli się znani im opiekunowie/terapeuci, zapewniając tym samym "dyskretną", wspierającą pomoc/wspomaganie, o ile taka zaistnieje potrzeba. Chodziło tutaj głównie o wsparcie w sytuacji, gdy trzeba zapisać propozycję wątków do dyskusji - jak wiadomo nie wszystkie osoby z głębszą niepełnosprawnością radzą sobie z samodzielnym pisaniem albo też w okolicznościach, 
kiedy konieczne było wsparcie $\mathrm{w}$ komunikowaniu się. Jak się zresztą okazało $\mathrm{w}$ trakcie toczącej się dyskusji, owego wsparcia w komunikowaniu się udzielali nie tylko opiekunowie/terapeuci, którzy niejako tłumaczyli to, co z trudem - ale jednak! - publicznie odważyła się powiedzieć konkretna osoba (ujawniając np. liczne utrudnienia wynikające z doświadczanych wad wymowy). Spontanicznymi translatorami były bowiem także inne osoby niepełnosprawne intelektualnie np. znajomi z tej samej placówki, którzy w codziennych kontaktach "oswoili się" ze sposobem komunikowania się i rozumienia danego podopiecznego.

Nie będę ukrywać, iż projektując program Festiwalu towarzyszyło nam odczucie pewnego niepokoju i niepewności w odniesieniu do tego jak potoczy się dyskusja z zastosowaniem TOP oraz czy - zaplanowana wprawdzie - swoboda i swoisty „brak kontroli” nad przebiegiem przedsięwzięcia nie okaże się zgubny i jak odnajdą się w nim uczestnicy z niepełnosprawnością intelektualną.

Jakże zatem budującym zaskoczeniem, o bardzo pozytywnym wydźwięku było to, że spontanicznie, okazując zainteresowanie włączyli się oni do grupy. Co więcej, w chwili, gdy osoba prowadząca poprosiła o zgłaszanie propozycji wątków/kwestii do dyskusji, kilkoro spośród niepełnosprawnych intelektualnie uczestników wyraziło chęć do zgłoszenia własnego tematu, o którym chcieliby porozmawiać. Nie radząc sobie z własnoręcznym zapisaniem go na kartce, prosili o pomoc osobę prowadzącą albo któregoś z opiekunów. Bardzo cieszyli się, gdy zgłoszona przez nich propozycja zagadnienia do dyskusji znalazła się/została zapisana na ogólnej tablicy, wśród wszystkich innych zgłoszonych tematów/ wątków) i została na głos wobec wszystkich odczytana; pojawiały się wówczas głosy i okrzyki radości: „o, to moje!, to ja, to ja powiedziałam! Pani Basiu, pani Basiu, pani widzi? To myśmy zgłosili, nie?!". Odnotować należy, iż po raz pierwszy spotkaliśmy się z tak licznym, aktywnym, ożywionym, i bez wątpienia śmiałym i odważnym, udziałem tych osób w poszczególnych formujących się grupach i w których w dalszej części spotkania toczyły się rozmowy. Ostatecznie bowiem, na podstawie zgłoszonych propozycji, skonkretyzowane zostały wątki tematyczne. Było ich pięć, co w konsekwencji ukonstytuowało pięć zespołów, które obradowały w rozproszeniu, lokując się w oddzielnych miejscach obszernej sali, całość zaś w ten sposób realizowanej dyskusji trwała sześćdziesiąt minut.

Moim bezpośrednim doświadczeniem stał się udział w dyskusji realizowanej przez jeden z zespołów, który toczył rozmowy wokół zaproponowanego „z sali” hasła: „Upełnomocnienie: szanse i zagrożenia”. Grupę stanowiło dwanaście osób, w tym pięć z niepełnosprawnością intelektualną - chcę zatem przede wszystkim pokazać to, jak zaznaczyli oni w niej swoją obecność, wnosząc do rozmów własny głos, wyrażający ich własny punkt widzenia, jednostkowy ogląd określonych zjawisk i spraw - wyraźny znak indywidualnych doświadczeń i subiektywnie przeżywanego świata. 
Poniżej złączam fragmenty z moich notatek terenowych, które sporządziłam $\mathrm{w}$ trakcie trwania dyskusji, zaznaczając jednakże, iż wypowiedzi było znacznie więcej; niektóre z nich obszerne, inne stanowiło zaledwie jedno bądź kilka wypowiedzianych zdań. Uznając wszystkie za jednakowo znaczące i ważne, dla potrzeb niniejszego opracowania z konieczności wybrałam jedynie kilka, a które egzemplifikują wątki i treści wyartykułowane $\mathrm{w}$ trakcie dyskusji przez osoby z niepełnosprawnością intelektualną:

(fragment zapisu w notatce terenowej)

Rozmowa toczy się wokół upełnomocnienia, po raz kolejny rozprawiamy o tym, co to faktycznie znaczy być upełnomocnionym, jakie prawa się tym wiążą, co upełnomocnienie zmienia w sytuacji człowieka niepełnosprawnego. Głos, między innymi, zabiera mężczyzna - uczestnik R. Przedstawia się jako podopieczny środowiskowego domu samopomocy, zwraca uwagę na to, że upełnomocnienie, w tym także zrównanie praw osób niepełnosprawnych, usytuowanie ich w pozycji klienta/petenta/pracownika niesie ze sobą, oprócz oczywistych korzyści, także i pewne zagrożenia. Podaje przykład sytuacji, w której takie osoby mogą zostać nieuczciwie zmanipulowane czy wykorzystane, $\mathrm{np}$. w okoliczności podpisywania różnych dokumentów, umów, np. zakup telefonu komórkowego, różne okazje i oferty atrakcyjnych zakupów, a nawet fikcyjnych umów o pracę:

Bo, dajmy na to - mówi R. - idziesz gdzieś do galerii ( handlowej) i tam, różni tacy, różni tacy podchodzą, zaczepiają i na ten przykład, nie? Na ten przykład, tam coś ci chcą wcisnąć! I może tak być, że ty się podpiszesz tam, podpiszesz, a potem trza płacić raty wielkie! Albo może być, że teraz my, my jako, że ci niepełnosprawni dostajemy pracę. Gdzieś tam dorywczo, bo na ten przykład jakiś jest projekt, nie? My tu mamy...,yy, nasi opiekunowie,... tu takie projekty są. I idziesz do tej pracy i może być, że ten..., ten w firmie, co masz tą pracę, oszuka, bo mniej zapłaci, nie? No, może tak być! Albo tam, gdzie indziej pójdziesz, dajmy na to, i..., i bez umowy cię wezmą i potem oszukają. Albo, albo, że ..., tam dadzą ci do podpisania, podpisujesz, nie? I potem się dowiadujesz, że tam niby pracujesz, a nie pracujesz, nie chodzisz, tam, do żadnej pracy, nie?

Ten wątek wzbudził ożywioną i naprawdę ciekawą rozmowę, w której zwrócono uwagę na to, że upełnomocnienie osób z niepełnosprawnością, choć samo $\mathrm{w}$ sobie jest pozytywne, może paradoksalnie zarazem stanowić pewne zagrożenie, wiążące się z ryzykiem manipulacji czy w nieuczciwy sposób wykorzystania konkretnych osób, zwłaszcza w sytuacji, gdy konieczne jest pełne zrozumienie treści podpisywanych dokumentów. Mówi o tym inna uczestniczka dyskusji-M., kobieta z niepełnosprawnością intelektualną, na co dzień związana ze środowiskowym domem samopomocy:

Bo my chcemy być samodzielni, żeby tak samemu..., jak to się mówi, nie? Mam dowód osobisty i ktoś może nam powiedzieć, że, że ...., ale już z tym czytaniem, to ja nie 
umiem sama tyle, tyle, szybko czytać! I tam ci dadzą do podpisania, i ja nie do końca wiem..., nie wiem, co podpiszę i dowód daję. Raz tu była na ośrodku taka sprawa, że J. dał dowód, podpisał w banku, a nic nie dostał, a musiał płacić. I dopiero tu opiekunowie poszli i załatwili, że tam z tym płaceniem nie musiał!

Nietrudno się domyślić, że kobieta - wprawdzie z mozołem, ale z dużym zaangażowaniem i z przekonaniem - mówiła o sytuacji wykorzystania, zmanipulowania osoby niepełnosprawnej przez nieuczciwe osoby trzecie w celu uzyskania kredytu/pożyczki w banku, którą w konsekwencji pożyczający musi spłacać. Opisana tu okoliczność jawi się jako potencjalne zagrożenie, o ile w kontekście upełnomocnienia uznajemy obywatelskie prawo niepełnosprawnego do zawierania umów cywilno-prawnych, np. kredytowych, kupna-sprzedaży, świadczenia rozmaitych usług, w których osoba z niepełnosprawnością może stać się jedną ze stron umowy, nie mając jakkolwiek pełnego rozeznania i świadomości co do czynności, w których dodatkowo niekoniecznie z własnej woli uczestniczy. Kwestie, które w swoich wypowiedziach wyartykułowali wymienieni dyskutanci, nie sposób uznać za błahe czy nie warte uwagi, tym bardziej na podkreślenie zasługuje fakt, iż osoby te wykazują swoiste wyczulenie i w trafny sposób identyfikują oraz opisują możliwe zagrożenia, w jakie mogą zostać uwikłani.

W kontekście rozmowy o potencjalnych niebezpieczeństwach, jakie paradoksalnie mogą wiązać się z upełnomocnieniem niepełnosprawnych i poszerzeniem zakresu swobody, samodecydowania i samodzielności w działaniu, pojawił się także wątek dotyczący znaczenia i roli - obecności/udziału innych osób w życiu człowieka z niepełnosprawnością intelektualną. Taką osobą - zdaniem dyskutantów - jest np. terapeuta/opiekun, w placówce, z którą związana jest osoba niepełnosprawna. Wyraźnie mówi o tym R.:

Ośrodek, to jest jak gdyby drugi dom, nie? I my tu mamy opiekunów. I ten, na ten przykład, opiekun może nam powiedzieć, pomóc, żebyśmy nie podpisali tam czegoś. On tam powie: "to nie jest dobre dla ciebie albo zastanów się czy to chcesz". On tam nie da krzywdy zrobić! Możesz zawsze do opiekuna pójść i tam powiedzieć, się poradzić. I ja wiem, że on zawsze dobrze poradzi, po twojej stronie będzie, nie? Jak to się mówi, pełne zaufanie, nie? Już wiesz, że nie jesteś taki sam, że jak się ma problem, to jest..., opiekunowie..., jest opiekun i on cię nie zostawi.

Podobnie rolę opiekuna/terapeuty widzi kolejna osoba włączająca się do dyskusji, E., która przedstawiła się jako uczestniczka warsztatu terapii zajęciowej:

Opiekunowie, na ośrodku, zawsze dla nas są. Bo my..., yyy, to wiadomo, nie zawsze człowiek wie, jaki ma, jakie ma prawo i co tam..., jaki ma te, no, uprawnienie. Różne tam jakieś prawa, że... yy y, bilety tańsze albo rente. No, to opiekunowie na ośrodku, zawsze możesz zapytać i oni powiedzą, jak masz zrobić, żeby tobie było dobrze, żeby było w porządku,...y było. Czasem ja się źle czuję, bo to głowa boli, oczy bolą, to zaraz opiekun poradzi gdzie iść, co zrobić. Albo tam, tam do urzędu i do jakiej urzędniczki 
i już, zaraz wiesz,... Tam pójdzie się, z mamą, yyy, nie z babcią poszłam, i, i nam, tam wodę naprawili. I już woda leciała z kranu!

Z kolei M. dodaje:

Opiekunowie to nie tylko na ośrodku z nami są. Jak potrzeba, to i wiedzą, co jest poza ośrodkiem. Bo to się tak mówi, weź i bądź samodzielny! Ja bym chciała. Bym chciała tak..., ale, ale weź idź i se załatw wszystko. Nie wszystko się..., się da załatwić. To już ten opiekun na ośrodku doradzi. Mi tam pani A. ..., tam porozmawiała, widziała, co ja chcę. Że bym pracować chciała, i tam zadzwoniła, tam popytała i pomogła, nie!

Z zacytowanych wypowiedzi uczestników rozmowy wnioskuję, że bardzo ważną postacią w życiu osoby niepełnosprawnej intelektualnie jest terapeuta/ opiekun, który wspierając, pomagając danej osobie, buduje zarazem poczucie swoistego bezpieczeństwa i pewności, że można na niego liczyć, obdarowując pełnym zaufaniem. Pomimo bowiem (perspektywy i potencjalnej) wolności, autonomii, samodzielności, rozumianych jako postulat i zarazem cel do osiągnięcia w procesie (treningu) upełnomocniania, osoby z niepełnosprawnością intelektualną, jak przypuszczam, nie czują się pewnie. Wydają się nie w pełni dysponowani, by śmiało korzystać z możliwości, jakie mogą wynikać z upełnomocnienia, czerpiąc z tego zadowolenie i satysfakcję Nie mają też - jak się domyślam - wypracowanej gotowości, by samodzielnie poradzić sobie w rozmaitych sytuacjach, jak choćby tych związanych z poszukiwaniem pracy („,Mi tam pani A. ..., tam porozmawiała, widziała, co ja chcę. Że bym pracować chciała, i tam zadzwoniła, tam popytała i pomogła, nie!").

Pewne obawy, o ile dobrze wyczytuję to z treści wypowiedzi, budzi w nich perspektywa swobodnego, samodzielnego funkcjonowania wraz z dostępem do rozmaitych ofert, typowych dla codziennego bytowania. By zatem czuć się bardziej bezpiecznie i komfortowo, za nieodzowną i cenną uznają obecność innych, na których pomoc w różnych okolicznościach mogą liczyć. To, o czym mówią uczestnicy dyskusji, wskazuje konieczność wsparcia ze strony osób trzecich, niezależnie od wieku i sytuacji życiowej osoby z niepełnosprawnością intelektualną. Ten swoisty rodzaj uwikłania dostrzega M. Kościelska (2004, s. 8), wskazując, że „istotą niepełnosprawności jest zależność od innych (...)”, dylematem zaś, z rozwiązaniem którego musi (z)mierzyć się społeczeństwo wobec (deklaracji, postulatów i realizacji) upełnomocnienia jest „(...) wizja dorosłego życia osób niepełnosprawnych, w którym zapewnimy im w możliwie największym stopniu wolność i wspomaganie". By zatem podjąć zadanie, jakim staje się stopniowa, sukcesywna realizacja dążeń, by niepełnosprawni mogli doświadczyć swoistej równowagi pomiędzy niezależnością/autonomią funkcjonowania a udzielanym im wsparciem, ważne - między innymi - jawi się poznanie tego co sami w tej kwestii mają do powiedzenia. Aktywne włączenie i uczestnictwo w dyskusji o upełnomocnieniu, 
w której wybrzmiewają kategorie wolności, samostanowienia, nabywania i korzystania $\mathrm{z}$ należnych praw, swobody $\mathrm{w}$ decydowaniu czy samodzielności działania, $\mathrm{z}$ jednej strony staje się elementem (realizacji treningu) upełnomocnienia, z drugiej zaś, zarysowuje perspektywę widzenia samych osób niepełnosprawnych intelektualnie.

W wypowiedziach dyskutantów z niepełnosprawnością intelektualną zwraca uwagę fakt, iż artykułują oni więcej zagrożeń, niepewności i ostrożności, które dostrzegają/wyczuwają w ewentualnej zmianie warunków życia i funkcjonowania jako potencjalnego efektu upełnomocnienia. Tym samym za bardzo cenne i ważne dla nich doświadczenie należy uznać sposobność, jaką zyskali dzięki udziałowi w debacie, by wyrazić to jak sami widzą zaznaczające się przeobrażenia, które już oddziałują bądź mogą mieć wpływ na ich egzystencję. I jak się zarazem okazuje, osoby te nie pozostają bezwolnymi i nieświadomymi postaciami, niezdolnymi zarówno do współuczestniczenia w kreowaniu różnych doświadczeń, jak i dokonywania względem nich własnych odniesień i interpretacji. Wciąż zatem wiele pozostaje do zrobienia "(...) na rzecz zmiany społecznego obrazu osób z upośledzeniem umysłowym, normalizacji warunków życia tych ludzi i ich integracji ze społeczeństwem”. A także, by ostatecznie uznać, iż "(..) osobom upośledzonym po prostu należy się, żeby mogły się wypowiedzieć w swoich sprawach." - co już przed laty z mocą podkreślała M. Kościelska (1995, s. 8-9), szczególnie akcentując, iż niepełnosprawni intelektualnie to ludzie, "(...) którzy mają osobiste problemy, swój sposób widzenia świata, przeżycia emocjonalne i (...) swoje prawo do głosu". Nawet, a może zwłaszcza, w tak doniosłych i skomplikowanych kwestiach jak te, które dotyczą upełnomocnienia, wolności i obywatelskich praw.

Pomimo iż od wydania publikacji autorstwa cytowanej autorki, zatytułowanej „Oblicza upośledzenia”, upłynęło sporo czasu, wygłoszone przez nią postulaty oraz zarysowane wówczas perspektywy zmian nadal wydają się zadaniem nie $\mathrm{w}$ pełni zrealizowanym. Osobiście za rzecz stale domagającą się udoskonalenia uważam równoważenie i upełnomocnienie głosu osób z niepełnosprawnością intelektualną, stwarzanie im szansy, by mógł on wybrzmieć niebędąc wyciszany w relacji z nawet najbardziej oddanym i wspierającym "pomagaczem”.

Wypowiedzi kolejnych dyskutantów, którzy włączyli się do rozmowy, wydają się egzemplifikować napięcie, jakie wyraźnie daje o sobie znać w relacjach z osobą niepełnosprawną. Jawi się nim trudność w wypracowaniu równowagi pomiędzy wolnością i wspomaganiem na osi działań opiekuna/terapeuty i podopiecznego, funkcjonujących na co dzień w placówkach wsparcia. Fragmenty rozmów, które poniżej cytuję, sytuują oba wymienione podmioty w niesymetrycznej/nierównorzędnej relacji, co sprawia, iż sposób widzenia "pomagacza” przez niepełnosprawnych uczestników zespołu dyskutującego jawi się odmiennie, ani- 
żeli prezentowali go przedmówcy. Oto zatem, co w odniesieniu do zarysowanej kwestii miała do powiedzenia W., uczestniczka warsztatu terapii zajęciowej:

(fragment z notatki terenowej)

Bo, ten, nooo, opiekun, on też może kazać coś robić w ośrodku, i ja muszę to robić, bo on tu jest kierownikiem, i jak ja..., jak ja tego nie zrobię, to może będzie niezadowolony, ale ja, ja może nie lubię robić tego, co opiekunowie każą?! Ja nie lubię malować, malowanie nie lubię, a oni mi każą! I ja muszę to robić. Pani opiekunka na pracowni każe robić, to ja robię i..., i dopiero jak pozwoli, to, to, możesz nie robić.

R. dodaje:

(...) każdy powinien robić do czego się nadaje, nie? Dajmy na to, jeden lubi występować, rozumiesz, nie? W grupie teatralnej grać, inny tam gotuje, śpiewa, coś tam robi. A jak nie chce, to niech nie przychodzi do ośrodka. Bo są też tacy, co oni nic nie chcą robić. I zamęt tylko przez nich, nie?

W. kontynuuje, bardzo emocjonalnie, ekspresyjnie, wypowiadając się głośno - by nie powiedzieć krzykliwie i ze złością, sporo przy tym gestykulując:

A opiekuny każą robić i musisz! I kierownik powiedział, że oni chcą ... A my chcemy inne rzeczy! I oni nas muszą spytać..., yy, się zapytać, co się chce. A nie tak! Że tylko każą i mówią, co robić. Że przychodzisz, i, i..., opiekuny już mówią, już tam rozdzielają, co masz robić. I opiekun rządzi, a inny nie!

Milczący dotąd mężczyzna, uczestnik warsztatu terapii zajęciowej, G. podobnie jak poprzedniczka głośno, doniośle, z przekonaniem i swoistą pewnością siebie mówi:

Wolność! Więcej wolności i ciekawych zajęć! A nie takich, jak w ośrodku chcą. Nas się też trzeba pytać! I my tam bez gadania kierownikowi powiemy. Bo niepełnosprawny też ma swój rozum i sam gadać może, a nie, że nas nie pytają, co my chcemy, nie?! Wolność! Bo w domu też..., to siostra i szwagier, oni se robią, jak..., jak,... y, y, nie pytają się nikogo, tylko po swojemu! To niepełnosprawny nie może?! Też może!

Zaprezentowane powyżej fragmenty wypowiedzi osób niepełnosprawnych intelektualnie mówią niejako same za siebie; są czytelne i sugestywne. Dość powiedzieć, że wyrażają wprost stanowczą niezgodę na przedmiotowe i mało partnerskie relacje z podopiecznymi, jakie nawiązują z nimi terapeuci/opiekunowie czy osoby sprawujące rolę kierowniczą w placówce. A nadto, dyskutanci artykułują brak aprobaty dla takiego usytuowania/traktowania, które sprawia, że niejako z konieczności/przymusu uczestniczą $\mathrm{w}$ określonych zajęciach, pomimo iż nie czerpią z nich żadnej przyjemności ani satysfakcji. Tkwią $\mathrm{w}$ takim położeniu powodowani i zobligowani przekonaniem, że: „Pani opiekunka na pracowni każe robić, to ja robię i..., i dopiero jak pozwoli, to, to, możesz nie robić". Naszkicowany 
tu kontekst sytuacji wydaje się ilustrować nie tylko zachwianie równowagi pomiędzy wolnością i wspomaganiem, upełnomocnieniem i manipulacją - nawet jeśli na realizację wymienionych idei/postulatów spojrzymy ograniczając się do środowiska jednostkowych placówek wsparcia, nie zaś w kontekście szeroko rozumianej przestrzeni społecznej. Wyraźnie też zaznacza się tu wyciszenie głosu podopiecznego: „nie pytają się nikogo, tylko po swojemu!”, co wydaje się powielać utrwalone i jak widać niełatwe do przezwyciężenia przekonanie, że w relacjach $\mathrm{z}$ osobami niepełnosprawnymi intelektualnie podejmuje się zwykle działania „,na ich rzecz", , ,w imieniu”, , dla nich", a niekoniecznie „z nimi”, ,„wspólnie", „podążając za”. Najpewniej taki sposób kreowania relacji przez opiekunów/terapeutów nie wynika ze złej woli czy rozmyślnego działania w intencji nieliczenia się z niepełnosprawnymi - jednak, wygląda na to, że tak właśnie owe relacje mogą być przez nich odbierane.

Uznając upełnomocnienie zarówno jako proces, jak i pewien etapowo osiągany stan można, jak sądzę, powiedzieć, iż osoby z niepełnosprawnością intelektualną zabierając głos $\mathrm{w}$ dyskusji dały wyraz rozbudzaniu się poczucia, że mogą zabrać głos we własnej sprawie. Poczuli się na swój sposób kompetentni i sprawni na tyle, by nabrać śmiałości do wyrażenia tego jak widzą i przeżywają zdarzenia, których doświadczają/mogą doświadczyć oraz związane z nimi okoliczności i sprawy, a także podzielić się tym w obecności wielu nieznajomych osób na forum. Wydają się ponadto trafnie identyfikować i opisywać określone sytuacje i konteksty społeczne, które odpoznają jako niekorzystne bądź wręcz opresyjne, a jednocześnie, rozeznając własne słabe strony i utrudnienia, wiedzą jaki gdzie mogą szukać pomocy i wsparcia - w przekonaniu, że mają do tego prawo.

Zaproszenie do udziału w Festiwalu, wiążące się z włączeniem do dyskusji osób dorosłych z głębszą niepełnosprawnością intelektualną traktuję zarówno jako przykład realizacji upełnomocnienia tej grupy, jak i swoisty trening upełnomocnienia. Widzę w nim szansę/sposobność do „ćwiczenia” pewnych zachowań i działań związanych z aktywnością w przestrzeni międzyludzkiej, angażując weń umiejętności i kompetencje w zakresie komunikowania się. Upełnomocnienie - jako element wiodącego/przewodniego hasła prezentowanej edycji Festiwalu Akcept jest jednak w niniejszym tekście jedynie pretekstem do namysłu i dyskusji nad inną kwestią, którą eksponuję, a mianowicie nad samym faktem udzielenia niepełnosprawnym głosu. Nie podejmuję dalszej, bardziej drobiazgowej aniżeli powyżej ukazana, analizy wątków związanych z problematyką upełnomocnienia, które pojawiły się w wypowiedziach osób z niepełnosprawnością intelektualną podczas opisywanego wydarzenia - mogłyby one z pewnością stanowić przedmiot osobnego opracowania.

Za główny cel mojego artykułu przyjęłam bowiem zwrócenie uwagi na to, że osoby z niepełnosprawnością intelektualną włączając się do dyskusji - do czego 
stworzono im warunki - okazują się nie tylko władne zabrać w niej głos, w pewien sposób uwikłać się w rozmowę adekwatnie do jej tematu, ale i rozmowę tę zupełnie skutecznie współkonstruować. Oczywiście głos ten - w zależności od wypowiadających się osób był bardzo zróżnicowany, często naprawdę bardzo wątły, niedoskonały, wyrażany z niemałym trudem, mozolnie i konieczne było jego wzmacnianie - angażujące udział innych, od których to także wymagało wzmożonej uwagi i koncentracji, by w taką narrację się wsłuchać. W odniesieniu do innych osób, ekspresja wypowiedzi, ton głosu, towarzysząca temu gestykulacja czy mimika, a nawet używanie zupełnie niecenzuralnych określeń czy zwrotów również wpisana została $\mathrm{w}$ charakterystykę głosu dyskutantów z niepełnosprawnością intelektualną. No, cóż: z punktu widzenia Bachtinowskiego karnawału, chwilowego „świata na opak" usankcjonowane i uprawnione pozostają wszelkie zachowania i formy manifestacji, dla których w życiu pozakarnawałowym trudno by o aprobatę. Tu jednak zarówno z racji na "niezwyczajność" wydarzenia, jak i na pewne właściwości dyskutantów (związane) z niepełnosprawnością intelektualną, funkcjonowanie uczestników dyskusji stanowi, rzec można, pewien koloryt karnawałowego widowiska, w którym uprawnione są różne style i zachowania. Tym samym, ów w pewien sposób głos specyficzny, będący niewątpliwie pochodną kondycji danych osób, powodowanej m.in. utrudnieniami jakich doświadcza z powodu niepełnosprawności intelektualnej to głos bardzo doniosły i ważny, który za sprawą umocnienia podczas karnawałowego świata wybrzmiewa pełnym dźwiękiem. Wydobywa bowiem sposób $\mathrm{w}$ jaki osoby dorosłe z niepełnosprawnością intelektualną widzą określone kwestie; wskazuje, że mają w odniesieniu do wielu spraw własne poglądy, które budują z określonych sensów i znaczeń, uwzględniając także całą sferę emocjonalną i uczuciową oraz jej nieskrępowaną ekspresję. Natomiast bardzo rzadko - jak mi się wydaje - zyskują szansę publicznego wyrażenia własnego zdania, zaznaczenia swojej obecności $w$ wielostronnej dyskusji, stąd podkreślam też odwagę, śmiałość jaką wykazali tak aktywnie, zachowując pełen autentyzm, wypowiadając się.

Za wielce chwalebne uważam zatem stworzenie tym osobom okazji do mówienia i bycia wysłuchanym - stąd też pomysł, by taką lokalną inicjatywę społeczno-edukacyjną, jaką jest gdański Festiwal Akcept, przybliżyć. W jego działaniu bowiem widzę nie tylko wkład $\mathrm{w}$ realizację i trening procesu upełnomocnienia osób z niepełnosprawnością intelektualną - a którą to kwestię wyeksponowano $\mathrm{w}$ haśle wiodącym konkretnej edycji festiwalu. To także ważne przedsięwzięcie, które można rozpatrywać $\mathrm{w}$ pewnym społeczno-kulturowym kontekście, szczególnie referowanym do znaczeń jakie przypisywane są osobom z niepełnosprawnością intelektualną (zwłaszcza w stopniu głębszym) i ich dostępu - a raczej utrudnionego dostępu - do głównych nurtów życia społecznego. 
Otóż, jeśli społeczne umiejscowienie tej grupy odnieść do poglądów B. Bernsteina (1990), S. Halla (1987) czy J.M. Tortosy (1986), nietrudno skonstatować, iż osoby z niepełnosprawnością intelektualną zajmują zwykle marginalne pozycje w społecznym rozplanowaniu, pozostając - jak określa to S. Hall czy H. Bhabha w bezgłośnej, niemej pozycji. Osoba z niepełnosprawnością intelektualną rzadko postrzegana bywa jako kompetentny nadawca komunikatów językowych, zdolna do sensownych i celowych działań, włączając w nie zdolność do zabierania głosu we własnych sprawach. Festiwal Akcept - ma jak sądzę szansę i do tego aspiruje, by choć $\mathrm{w}$ pewnym stopniu stać się przestrzenią polemiki z wiedzą potoczną dotyczącą możliwości komunikowania się osób z niepełnosprawnością intelektualną oraz pełnienia przez nie istotnej roli jako jednej ze stron społecznego dyskursu, podejmującą wysiłek dialogowania i wyrażania własnych, osobistych znaczeń.

Tym samym, Festiwal Akcept kreując przestrzeń wielogłosowości, dialogu, dyskusji, do której - obok osób pełnosprawnych reprezentujących liczne i zróżnicowane środowiska i kompetencje - zaprasza dorosłych z niepełnosprawnością intelektualną, co wydaje się stanowić krok ku przełamaniu ich niemej, bezgłośnej pozycji, jaką zwykle nadal zajmują w społecznych lokalizacjach. Na marginesie warto zaznaczyć, iż tak specyficzne wydarzenia, jak debaty, seminaria czy konferencje, podczas których podejmuje się dyskusję wokół problematyki niepełnosprawności (intelektualnej) oraz osób z tym rodzajem niepełnosprawności, wyraźnie uprzywilejowanym czynią głos podmiotów legitymujących się statusem normalności/pełnosprawności. A nadto, jest to w przeważającej mierze głos środowiska akademickiego, dla którego właściwy pozostaje dyskurs mieszący się w określonej konwencji oraz wyrażający stanowisko i głos różnych dyscyplin naukowych. Dyskusja z zastosowaniem technologii otwartej przestrzeni realizowana podczas debaty, jako integralna część Festiwalu Akcept, nie jest wprawdzie wydarzeniem stricte akademickim, to jednak znaczącą większość dyskutantów stanowią osoby pełnosprawne, spośród których wielu często pełni np. znaczące funkcje w publicznych instytucjach, są tu także naukowcy wywodzący się z akademickich ośrodków szkolnictwa wyższego. A zatem realna próba aktywnego włączenia tak "słabego" głosu dorosłych z głębszą niepełnosprawnością intelektualną jawić się może zadaniem z jednej strony karkołomnym, z drugiej zaś śmiałą realizacją upełnomocnienia tej grupy. $Z$ tego względu - co niejednokrotnie podkreślałam w niniejszym tekście - Festiwal Akcept i dyskusja z zastosowaniem TOP warta jest bliższej prezentacji. 


\section{Festiwal Akcept jako Bachtinowski karnawał}

\section{Życie z istoty swej jest dialogowe. Żyć - to uczestniczyć w dialogu: pytać, stuchać, ponosić odpowiedzialność, aprobować itp.}

M. Bachtin

Podejmując rozważania, w których koncentruję się na prezentacji Festiwalu Akcept jako artystycznego wydarzenia mieszczącego się w polu lokalnych inicjatyw kulturalno-edukacyjnych, zorientowanych na szeroko rozumiany dialog, gdzie równouprawnione są i umiejscowione w partnerskiej komunikacji różne/różniące się podmioty, interesującym i zasadnym wydaje się, aby owe rozważania umieścić $w$ inspiracji karnawału/karnawalizacji M. Bachtina.

Nadmieniałam już we wstępie, iż festiwal i karnawał to zbliżone do siebie w swej naturze fenomeny, które spaja odświętność i niecodzienny charakter, nadając obu wydarzeniom cechy niezwykłości i niezwyczajności, jakim ponadto towarzyszy czasowe zawieszenie rutyny życia potocznego, unieważniając typowy, utrwalony, tradycyjny porządek i ład codzienności. Zarówno festiwal, jak i karnawał gromadzą licznie przybyłych ludzi, wywodzących się zazwyczaj w różnych środowisk i lokalizacji społecznych, którzy w radosnej atmosferze (świętowania) kultywują spotkanie, nawiązują kontakty czy też zacieśniają relacje, a towarzyszy temu i wszystko to scala wielość sytuacji i aktów porozumiewania się - dialogiczne komunikowanie. Karnawał jako czas głośnej i radosnej zabawy pośród tańców i pląsów przy muzyce i w takim aspekcie znajduje swoje uobecnienie podczas Festiwalu Akcept. Wprawdzie nie poruszam tego wątku w tym opracowaniu, ale jedynie gwoli informacji podaję, iż wyczekiwanym elementem tego corocznego wydarzenia jest dyskoteka i wszelkie związane z nią atrakcje. Organizowana jest zawsze $\mathrm{w}$ pierwszy festiwalowy dzień w znanym trójmiejskim klubie Miasto Aniołów, położonym nad Motławą w Gdańsku, po wodach której tego wieczoru niesie się gromka wrzawa, hałaśliwe śpiewy i tańce - jak przystało na iście „karnawałowe życie ludu".

Festiwal (Akcept) wydaje się wyraźnie splatać z karnawałem, w szczególności zaś dopatruję się w nim właściwości karnawału w rozumieniu M. Bachtina. Jako wydarzenie artystyczne i zarazem zaproszenie do dyskusji w technologii otwartej przestrzeni festiwal jawi się jako zjawisko zorientowane na spotkanie i dialog. Dialog żywy, spontaniczny, sytuujący w partnerskiej, możliwie najbardziej symetrycznej relacji podmioty, które mogą się od siebie nawet znacząco różnić (jeśli chodzi o zdolności i kompetencje czy własne społeczne usytuowanie i kulturowy kapitał doświadczeń biograficznych). Oto bowiem w przestrzeni (festiwalowej) dyskusji spotykają się (niczym) w bachtinowskim karnawale dwa podmioty: osoby pełnosprawne i z niepełnosprawnością intelektualną. Jak wskazuje M. Roma- 
nowska (http://www.filg.uj.edu.pl/documents/41616/105797965/Magdalena_Romanowska-streszczenie.pdf): „Dla Bachtina karnawał staje się miejscem spotkania biegunowo różnych wartości: nieba i piekła, Boga i diabła, góry i dołu. Karnawałowe formy (...) stają się środkami dla ujawnienia zupełnie nowych aspektów życia, stają się szczególnym językiem, symbolicznie odsłaniającym głęboki osobowy wymiar istnienia ludzkiego". Biorąc pod uwagę specyfikę funkcjonowania i (możliwości) komunikowania się osób z niepełnosprawnością intelektualną oraz osób pełnosprawnych nie sposób zaprzeczyć i zdyskwalifikować ich społecznego oddalenia - bywa, że w pozakarnawałowym życiu są sobie krańcowo/biegunowo odlegli. To jednak, przystępując razem do dyskusji podczas festiwalu rozumianego jako bachtinowski karnawał, ich wzajemne relacje i usytuowanie - niezależnie od przejawianej kondycji i doświadczanych ograniczeń i utrudnień - ulega swoistemu anulowaniu. Zbliżają się do siebie podczas rozmowy, podejmują starania, by rozmowę wspólnie budować i tworzyć, a zarazem wzajemnie się uważnie, cierpliwie i z pokorą słuchać. Jest ku temu sposobność, bowiem Bachtinowski model karnawału uobecniony podczas dyskusji w trakcie Festiwalu Akcept przełamuje i unieważnia granice oddzielające jednych od drugich. Wszyscy, którzy uczestniczą w karnawale, nie dystansują się ani wobec siebie, ani wobec toczących się spontanicznie zdarzeń, lecz aktywnie je tworzą i przeżywają: wszyscy stają się równoprawnymi i równymi sobie uczestnikami tzw. "karnawałowego życia”, włączając się w jego bieg i respektując jego reguły. Jak zauważa M. Kowalczyk (http://www.publio.pl/files/samples/c2/e2/86/76473/Tyrmand_karnawalowy_demo.pdf) „Stąd nieprzypadkowo Bachtin określa to zjawisko jako «drugie życie ludu». (...) W tym uroczystym czasie bowiem nie było życia poza karnawałem, wszyscy stawali się składnikami i uczestnikami tzw. «życia karnawałowego», którym kierowała zasada «świata na opak», mieszcząca wiele form realizacji. Dlatego też recepcja świata karnawałowego musiała się różnić od recepcji codziennej, nieświątecznej rzeczywistości. Rosyjski badacz posługuje się tu (...) terminem «światoodczucie karnawałowe» i stara się uporządkować zjawiska tworzące ów «świat na opak», ujmując je w ścisłe ramy. (...) Pierwszą z nich jest nowy układ stosunków międzyludzkich. Chodzi tutaj o zanik wszelkich przywilejów wynikających $\mathrm{z}$ urodzenia, rangi, wieku czy też wykonywanego zawodu. Następuje zrównanie wszystkich ze wszystkimi, plac karnawałowy nie zna bowiem «lepszych» $\mathrm{i}$ «gorszych». Nieważne kim był uczestnik w świecie pozakarnawałowym, widowisko pozbawia go wszelkich przywilejów. Oczywiście sprawdza się to jedynie w specyficznych warunkach karnawału, w innym przypadku byłoby to niemożliwe".

Tak też dzieje się z uczestnikami festiwalowej debaty odbywającej się w konwencji technologii otwartej przestrzeni: jest ona zaprojektowana w taki sposób, aby mógł w niej wziąć udział każdy, niezależnie od tego kim i jaki jest/jaka jest jego kondycja, doświadczenia i kompetencje. Pełnosprawni i niepełnosprawni 
(intelektualnie) nie tylko zasiadają obok siebie, ale i każdy z nich ma możliwość oddziaływania na treść i przebieg dyskusji; nie ma lepszych czy gorszych uczestników, podobnie jak nie wartościuje się pomysłów czy propozycji wątków/kwestii do rozmowy. Jest tu miejsce, by zaznaczyć swoją indywidualność, zaistnieć wygłaszając zdanie, wejść w dialog, włączając się i współtworząc społeczny proces uzgadniania i wymiany sensów i znaczeń nadawanych sobie, innym, światu. Pełnosprawny dyskutant nie zajmuje wyższej i uprzywilejowanej pozycji wobec uczestnika z głębszą niepełnosprawnością intelektualną, pomimo iż oboje zwykle różnią się potencjałem i kompetencjami. W świecie pozakarnawałowym, gdy festiwal i debata się kończą, ich relacja na powrót staje się bardziej niesymetryczna i powracają do układu respektującego zwykłe usytuowanie. Tymczasem podczas festiwalowej dyskusji pełnosprawny student, przedstawiciel znaczącej organizacji pozarządowej, reprezentant władz miasta, polityk, naukowiec - stosując się do reguł debaty realizowanej w TOP - cierpliwie słucha tego co często ze sporym mozołem i wysiłkiem, przezwyciężając własne ograniczenia, wady wymowy, pokonując niepewność i skrępowanie jakie wzbudza sytuacja ekspozycji społecznej, ma do powiedzenia osoba z niepełnosprawnością intelektualną.

Dyskwalifikacja pełnionych w codzienności ról, stanowisk, wzięcie w nawias kondycji uczestników debaty rozgrywającej się w karnawałowym świecie, eksponuje rolę dialogu, który dla Bachtina staje się kategorią centralną. Dialog, „niezwieńczony dialog", w opozycji do "podejścia zmonologizowanego", jawi się ,jedyną adekwatną formą językowej ekspresji prawdziwego życia człowieka (...). Życie z istoty swej jest dialogowe. Żyć - to uczestniczyć w dialogu: pytać, słuchać, ponosić odpowiedzialność, aprobować itp. (...)" - mówi Bachtin (1986, s. 453). Dyskusja w technologii otwartej przestrzeni łączy dialogujących ze sobą dyskutantów pełnosprawnych i z niepełnosprawnością intelektualną, a dokonuje się to przy zawieszeniu dotychczasowego porządku/układu społecznych ról, typowych dla potocznego życia w zhierarchizowanym świecie stosunków międzyludzkich. Zaprojektowana w odmienny sposób (jak gdyby na nowo), odświętna rzeczywistość - „,karnawałowe światoodczucie” - może sprawić, iż dyskutanci, wikłając się w rozmowę, mają szansę ujrzeć siebie w innej perspektywie i nieco bardziej przybliżyć się do prawdy o sobie. M. Romanowska (http://www.filg.uj.edu.pl/documents/41616/105797965/Magdalena_Romanowska-streszczenie.pdf), interpretując myśl Bachtina wyjaśnia, iż: „Prawda rodzi się w wydarzeniu międzyludzkim, w procesie dialogu. Karnawał (...) stwarza wyjątkową sytuację oczyszczającą słowo od wszelkiego życiowego automatyzmu i pretensji na obiektywność, zmusza człowieka do odkrycia wewnętrznego jądra własnego człowieczeństwa. Poddanie próbie idei jest poddaniem próbie człowieka i jego osobowej prawdy".

Traktując dyskusję podczas Festiwalu Akcept jako czas „świata na opak" i uwzględniając jedynie czasowe trwanie „Życia karnawałowego" oraz jego swoistą 
chwilowość upatruję w nim szansy na zainicjowanie stopniowej zmiany znaczeń, jakie wzajemnie przypisują sobie uczestnicy debaty. To niewątpliwie czas, gdy do głosu dochodzą ci, którym doświadczana niepełnosprawność intelektualna zwykle uniemożliwia, a w każdym razie znacząco utrudnia, dostęp do wypowiadania się, zwłaszcza w publicznej przestrzeni. Nieczęsto też bywają postrzegani jako podmioty zdolne do świadomego, intencjonalnego i sensownego nadawania komunikatów językowych, ujawniających sensy i znaczenia, jakie nadają światu, który na swój sposób porządkują i przeżywają. W karnawałowym świecie Festiwalu mają do tego sposobność. Bachtinowski karnawał zawiesza codzienność, w której osoba z niepełnosprawnością intelektualną, bytując przeważnie na uboczu/na marginesie głównego nurtu życia, nie ma zbyt wielu możliwości by zaznaczyć swoją obecność w różnych środowiskach i wobec rozmaitych ludzi, nie zawsze bywa słyszana i (wy)słuchana.

Podobnie dzieje się w odniesieniu do osób pełnosprawnych - reprezentujących rozliczne lokalizacje społeczne, pełnione $\mathrm{w}$ nich role i podejmowane zadania, nawet te, które wiążą się z profesjonalnym znawstwem obszaru splecionego z pomocą, wsparciem, rehabilitacją czy edukacją osób z niepełnosprawnością. W potoku codziennych działań, rutyna potoczności uśmierca niekiedy świeżość spojrzenia i odczuwania, zamykając na prawdę o człowieku, który jest wspomaganym podopiecznym. Czas karnawału jaki ustanawia Festiwal Akcept mąci rutynę codzienności, wprowadzając zaś (radosny) i odmienny nastrój święta, czyni okazję by spojrzeć na siebie inaczej, zawiesić dotychczasowy zasób wiedzy i doświadczeń, wejść w dialog, niejako na nowo/od nowa. „Karnawał, będąc prawdziwym wymiarem życia, nie jest obiektem, ale przede wszystkim wydarzeniem ludzkiego komunikowania się, pozwala na zbratanie się ze światem, na familijność w stosunku do świata, zostaje w nim przezwyciężona obcość kosmosu i alienacja człowieka" - dopowiada M. Romanowska objaśniając intencje rosyjskiego filozofa (http://www.filg.uj.edu.pl/documents/41616/105797965/Magdalena_Romanowska-streszczenie.pdf).

Festiwal Akcept corocznie gromadzi sporą rzeszę osób z niepełnosprawnością intelektualną, dla wielu jest sposobnością zaistnienia w odmiennym niż codzienne, oswojone i familiarne środowisko. To okazja do spotkania innych bądź poznania nowych, zupełnie nieznanych, osób: bowiem w karnawałowym życiu wykracza się poza dobrze znane ramy zwyczajnej, potocznej egzystencji, nacechowanej często schematyzmem, rutyną, powtarzalnością czynności i zdarzeń, w których na ogół uczestniczą te same, dobrze znane postaci. Trzy festiwalowe dni to czas niezwykle intensywny, przepełniony wydarzeniami, z ferią dźwięków, barw, ferworu i gwaru, pełen dobrej energii i nasycenia pozytywnymi emocjami, jakich dostarczają spektakle teatralne, muzyka czy inne estetyczne wrażenia, których nie brakuje. Wszystko to niczym „powszechny sympozjon” angażuje uczestni- 
ków festiwalu, sprzyjając zapośredniczeniu ze światem, zniwelowaniu (jego) obcości, czy przełamaniu własnej słabości, nieśmiałości, przezwyciężeniu ograniczeń. Wydobyciu się - choćby na czas karnawału - poza to co swojskie, dobrze znane i bezpieczne, w czym paradoksalnie jednak czaić się może samotność (wyalienowanie), co ostatecznie sprawia, że w obliczu nowych doświadczeń pojawia się odczucie obcości i lęku.

Przezwyciężenie obcości i alienacji w rozumieniu Bachtina możliwe jest jedynie poprzez obecność innego: „Byt człowieka (tak zewnętrzny, jak i wewnętrzny) ziszcza sięw najgłębs zym porozu miew aniu się. Być-znaczy porozumiewać się" - powie Bachtin (1986, s. 444). Jeśli zaś na mocy reguł karnawałowego świata "na opak" udaje się oderwać od zwyczajności i potoczności, zagłębić się i spotkać w dialogu, to być może okaże się, iż ów obcy/inny objawi się „bardziej taki sam" aniżeli różny. A jeśli różny to wart poznania takim jakim jest. Bachtin (1986, s. 455) akcentuje, iż: „W owym spotkaniu j a winno przy tym występować jako ja głębokie, wydobywane z wnętrza nas samych, pozbawione jakiejkolwiek domieszki antycypowanych lub wymuszonych czy naiwnie konwencjonalnych punktów widzenia i ocen drugiego człowieka (...)". By o tym się przekonać, uzmysłowić sobie potencjalność odmiennej od dotychczasowej optyki wzajemnego widzenia siebie przez pełnosprawnych, i tych z niepełnosprawnością intelektualną: „,winienem odnaleźć siebie w innym, a jego odnaleźć w sobie (poprzez wzajemne odzwierciedlenie się, wzajemną afirmację). (...) To inny nadaje mi imię, które funkcjonuje potem dla innych (nadawanie imienia samemu sobie jest samozwańcze) - wyjaśnia Bachtin (1986, s. 445).

Rozmowa, porozumiewanie się, dialog - to formy, które rosyjski badacz uznaje za prymarne dla człowieka, wyraźnie i kategorycznie przeciwstawiając je specyficznemu stosunkowi $\mathrm{j}$ a oraz i $\mathrm{n} \mathrm{n}$ e g o, jaki typowy jest dla monologu/monologizowania. „W skrajnym przypadku - mówi Bachtin (1986, s. 452) monologizm wyklucza obecność poza sobą innej równoprawnej świadomości, równie uprzywilejowanej pod względem możliwości odpowiadania, innego równoprawnego j a (t y). (...) Monolog jest zamknięty i głuchy na cudze repliki, których nie oczekuje, ani tez nie przyznaje im mocy r o z s tr z y g a ją c e j. Obchodzi się bez innego. Dlatego do pewnego stopnia reifikuje całą rzeczywistość. Rości sobie pretensje , by stać się słowem o s t a t e c z n y m". Zupełnie tak, jak wyczytuję z relacjonowanej we wcześniejszej części tekstu wypowiedzi cytowanej kobiety z niepełnosprawnością intelektualną, która nie kryjąc oburzenia i rozgoryczenia, opisuje zachowania terapeutów w "swojej” placówce: „Że tylko każą i mówią, co robić". Sami - jak się domyślam - nie pytają i nie słuchają: monolog prawdopodobnie przytłacza dialog. Być może jednak, gdy racje obu stron - pełnosprawnego i niepełnosprawnego intelektualnie - zyskają szansę by w trakcie dyskusji wybrzmieć i zostać wysłuchane, zainicjuje to proces korygujący tak ukształtowane 
stosunki i sposoby komunikowania się. Konfrontacja z prawdą podopiecznego, który podczas karnawału znajduje się w znacząco bardziej symetrycznej relacji z pełnosprawnym (terapeutą), umożliwia wyartykułowanie tego co w świecie pozakarnawałowym być może nigdy by nie wybrzmiało. Życie karnawałowe wydaje się przestrzenią na tyle bezpieczną, iż wyzwala spontaniczną i nieskrępowaną ekspresję, a w konsekwencji pozwala by obie strony inaczej na siebie spojrzały, zapoczątkowując stopniową zmianę i przemieszczenia w polu wzajemnie przypisywanych sobie znaczeń.

Stanie się tak, gdy podczas Festiwalu nawiązany zostanie i będzie toczył się dialog. Dialog bowiem, jako przeciwieństwo monologu, wydobywa głos człowieka. W rozumieniu Bachtina (1986, s. 453) „mieści się w nim i światopogląd, i los człowieka. Człowiek partycypuje w dialogu jako tego typu totalny głos. Uczestniczą w nim nie tylko jego myśli, lecz także jego los, cała jego indywidualność" w tym sensie głos jawi się jako ekspresja "prawdziwego życia człowieka”. Festiwal Akcept i odbywająca się w jego ramach debata - jako „świat na opak" - wydaje się skutecznie wydobywa i równoważy głos wypowiadających się stron: osób pełnosprawnych i z niepełnosprawnością intelektualną.

\section{Zakończenie}

W zakończeniu niniejszego tekstu pragnę objaśnić (a może nawet zastrzec), iż czyniąc pewne odwołania do myśli i poglądów Bachtina, nie pretenduję bynajmniej do znawczyni twórczości tego autora, ani też nie deklaruję swobody w poruszaniu się w polu studiów nad recepcją jego dzieł. Zapoznanie się z wybranymi fragmentami pism Bachtina oraz posiłkowanie się opracowaniami innych badaczy, przywoływanych w artykule, okazało się dla mnie ciekawą inspiracją, by na Festiwal Akcept spojrzeć „oczami karnawału Bachtina”. Dość swobodne odwołanie się do zaczerpniętych myśli Bachtina uważam jakkolwiek za uprawnione, zwłaszcza w kontekście wypowiedzi M. Kowalczyka, (http://www.publio.pl/files/samples/c2/e2/86/76473/Tyrmand_karnawalowy_demo.pdf), który zauważa: „Bachtin ze swoimi badaniami sytuuje się na pograniczu różnych nauk humanistycznych - w równym stopniu zajmują go aspekty antropologiczne, etyczne, lingwistyczne i teoretycznoliterackie. (...) Choć polem jego działalności jest przede wszystkim literatura, uczony nie cofa się także przed korzystaniem z osiągnięć innych dyscyplin naukowych, takich jak: socjologia, psychologia, filozofia czy lingwistyka. Nic więc dziwnego, iż wielu naukowców zajmujących się różnymi dziedzinami humanistyki próbuje interpretować myśl Bachtina w kontekście własnych poglądów". 
Stąd i moje własne zainteresowanie Bachtinem i skromna próba implantacji niewielkich fragmentów jego twórczości do dyskusji nad wybranymi aspektami funkcjonowania dorosłych $\mathrm{z}$ niepełnosprawnością intelektualną $\mathrm{w}$ przestrzeni społecznej i wydarzeniami, które są im dedykowane. Kategoriami, które orientują moją wypowiedź są tutaj: spotkanie, dialog, wielogłosowość, symetryczna i partnerska relacja $w$ dyskusji, kreowanie nowego wzorca współbycia pomiędzy osobami z niepełnosprawnością intelektualną oraz pełnosprawnymi, wraz z sygnalnym odwołaniem do wątków związanych z upełnomocnieniem. Wszystko to zaś wydaje mieścić artystyczne wydarzenie, które raz do roku przełamuje rutynę codzienności, a jest nim Festiwal Akcept i debata w technologii otwartej przestrzeni,. Podczas trzech odświętnych i niezwyczajnych dni panuje „świat na opak": czasową rzeczywistość - „życie karnawałowe” i „karnawałowe światoodczucie”, w którym obowiązuje odmienny od tradycyjnie utrwalonego społeczny porządek i ład, zawieszeniu ulega dotychczasowy układ stosunków i ról, ustępując miejsca "niezwieńczonemu dialogowi”. Jawi się on wysiłkiem i wspólnym staraniem zróżnicowanych oraz różniących się podmiotów - osób pełnosprawnych i z niepełnosprawnością intelektualną, które wobec chwilowego unieważnienia i zniesienia dzielących je odmienności oraz różnic, starają się wzajemnie odnaleźć (na nowo) w "głębokiej dialogowości słowa".

M. Kowalczyk (http://www.publio.pl/files/samples/c2/e2/86/76473/Tyrmand karnawalowy_demo.pdf), przywołując stanowisko M. Gardinera, wyjaśnia, iż „(...) ważnym elementem karnawału jest eksponowanie egalitaryzmu oraz elementów skrajnej demokracji. Dzieje się tak poprzez stwarzanie utopijnej sfery nieskrępowanej wolności (likwidacja wszelkich formalnych hierarchii i zależności społecznych). Gardiner zwraca także uwagę, iż karnawałowa utopia nie jest «utopią abstrakcyjną», lecz, paradoksalnie, «utopią konkretną», gdyż przejawia się w realnych sytuacjach". Za przejaw takiej realnej sytuacji, w której dokonuje się realizacja owej „konkretnej utopii”, odważę się uznać wydarzenie jakim jest Festiwal Akcept, zwłaszcza zaś ta jego część, którą stanowi dyskusja z zastosowaniem TOP. W niej bowiem upatruję próby demokratyzowania relacji pomiędzy osobami pełnosprawnymi i z niepełnosprawnością intelektualną, osłabienia zhierarchizowanych i niesymetrycznych stosunków oraz relacji pomiędzy wymienionymi podmiotami, choćby przez wyciszenie głosu pełnosprawnych, a u(pełno)mocnienie tych, którzy doświadczają niepełnosprawności.

Debata podczas Festiwalu Akcept wydaje się zaczynem tego, co w pojęciu Bachtina (1986, s. 444 i 447) „ziszcza się w na j g łę b s z y m p o r o z u m i e w a n i u s i ę", gdy uczestniczące w nim strony - wobec anulowania tradycyjnego porządku i ról jakie pełnią w codzienności - w "karnawałowym świecie” zyskują szansę na "(...) krzyżowanie się horyzontów (swojego i cudzego), przecięcie dwu świadomości". 


\section{Bibliografia}

Angrosino M. (2010), Badania etnograficzne i obserwacyjne, Wydawnictwo Naukowe PWN, Warszawa.

Bachtin M. (1986), Estetyka twórczości słownej, PWN, Warszawa.

Bernstein B. (1990), Odtwarzanie kultury, wybrał i oprac. A. Piotrowski, PIW, Warszawa.

Bhabha H. (2010), Miejsca kultury, Wydawnictwo Uniwersytetu Jagiellońskiego, Kraków.

Bhabha H. (2008), Mimikra i ludzie. O dwuznaczności dyskursu kolonialnego, „Literatura na Świecie", nr 1-2, s. 184-195.

Burszta W.J. (1998), Antropologia kultury. Tematy, teorie, interpretacje, Zysk i S-ka, Poznań.

Danforth S. (1997), On what basis hope? Modern and postmodern possibilities, „Mental Retardation", vol. 35, no. 2, s. 93-106.

Hall S. (1987), Bezgłośny język, PIW, Warszawa.

Hammerslay M., Atkinson P. (2000), Metody badań terenowych, Zysk i S-ka, Poznań.

Kopaliński W. (1983), Stownik wyrazów obcych i zwrotów obcojęzycznych, Wiedza Powszechna, Warszawa.

Kościelska M. (2004), Niechciana seksualność, Wydawnictwo Jacek Santorski \& Co, Warszawa.

Kościelska M. (1995), Oblicza upośledzenia, PWN, Warszawa.

Krzemińska D. (2012), Dorośli z niepetnosprawnościq intelektualna w okowach "misji rehabilitacyjnej" - perspektywa postkolonialna [w:] D. Krzeminska, I. Lindyberg, Wokót dorosłości z niepetnosprawnościq intelektualną. Teksty rozproszone, Oficyna Wydawnicza „Impuls”, Kraków.

Krzemińska D. (2006), Kod językowy i dyskurs osób z niepetnosprawnościq intelektualną. O bytowaniu na pograniczu [w:] Świat peten znaczeń - kultura i niepetnosprawność, red. J. Baran, S. Olszewski, Oficyna Wydawnicza „Impuls”, Kraków.

Rzeźnicka-Krupa J. (2007), Komunikacja - Edukacja -Społeczeństwo. O dyskursie dzieci z niepetnosprawnością intelektualna, Oficyna Wydawnicza „Impuls”, Kraków.

Sulima R. (2000), Antropologia codzienności, Wydawnictwo Uniwersytetu Jagiellońskiego, Kraków.

Szarota T. (rok), Życie codzienne - temat badawczy czy tylko popularyzacja? (Na marginesie serii wydawniczych Hachette i PIW-u), „Kwartalnik Historii Kultury Matrialnej”, nr 34.

Sztompka P. (2009), Przestrzeń życia codziennego [w:] M. Bogunia-Borowska, Barwy codzienności. Analiza socjologiczna, Wydawnictwo Naukowe Scholar, Warszawa.

Tortosa J.M. (1986), Polityka językowa a języki mniejszości, PIW, Warszawa.

\section{Netnografia}

http://akcept.gak.webd.pl/

http://frisakces.wixsite.com/fundacja

http://kulturalny.uw.edu.pl/luty21/karnawal.htm

http://www.filg.uj.edu.pl/documents/41616/105797965/Magdalena_Romanowska-stresz-

czenie.pdf

http://www.openspaceworld.com/

http://openspaceworld.org/wp2/

http://www.wyspaskarbow.gak.gda.pl/o-nas/gdaski-archipelag-kultury

http://www.publio.pl/files/samples/c2/e2/86/76473/Tyrmand_karnawalowy_demo.pdf 